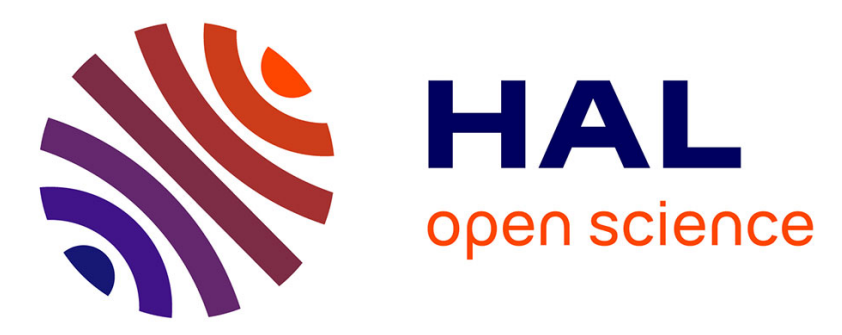

\title{
Errata - Possibilités de stockage de l'énergie solaire à partir de sulfates
}

\author{
M. Ducarroir, M. Tmar, C. Bernard
}

\section{To cite this version:}

M. Ducarroir, M. Tmar, C. Bernard. Errata - Possibilités de stockage de l'énergie solaire à partir de sulfates. Revue de Physique Appliquée, 1980, 15 (7), pp.1278-1278. 10.1051/rphysap:019800015070127801 . jpa-00244852

HAL Id: jpa-00244852

https://hal.science/jpa-00244852

Submitted on 1 Jan 1980

HAL is a multi-disciplinary open access archive for the deposit and dissemination of scientific research documents, whether they are published or not. The documents may come from teaching and research institutions in France or abroad, or from public or private research centers.
L'archive ouverte pluridisciplinaire HAL, est destinée au dépôt et à la diffusion de documents scientifiques de niveau recherche, publiés ou non, émanant des établissements d'enseignement et de recherche français ou étrangers, des laboratoires publics ou privés. 


\section{Errata}

\section{Possibilités de stockage de l'énergie solaire à partir de sulfates}

M. Ducarroir, M. Tmar et C. Bernard

Revue Phys. Appl. 15 (1980) 513-528.

Page 524 remplacer le tableau V par :

Tableau V. - Les calculs sont basés sur une mole de $\mathrm{SO}_{2}$.

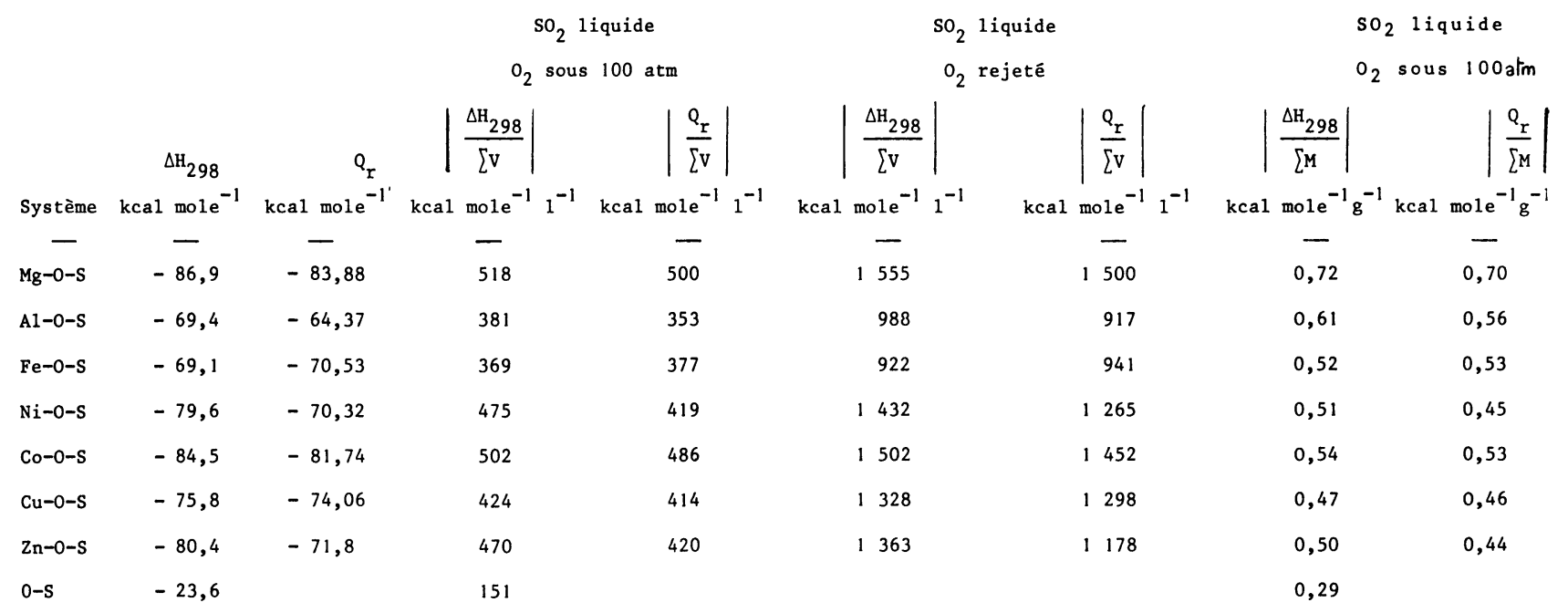

